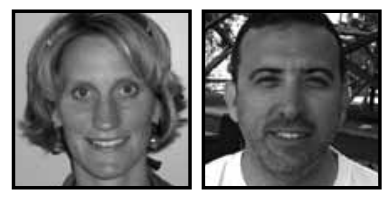

\title{
The Early Bird Gets the Worm: How Early Morning Exercise Creates Inspired Learners and Educators
}

\author{
Heather DeLaurentis \& David Howes
}

\begin{abstract}
As the nation grapples with how to shrink the achievement gap and raise the level of achievement for all students, educators need to rethink how they deliver instruction and how students learn. Sitting in chairs all day long is not the most conducive way to learn. It is critical that schools look towards morning movement and exercise programs to stimulate increased brain activity and energize children to be ready and able to focus on their academics throughout the day.
\end{abstract}

he last bus pulled out at 3:17 p.m. It had been a hectic day and as we sat
in the classroom waiting to begin a professional development session,
we began to trade stories about the various behavior referrals and even a threat of a fistfight. A few colleagues and I were chatting, as we typically do at the end of a long day, about ways to keep students engaged. We teach in a small urban school where we have a high percentage of economically disadvantaged students and a dedicated staff that is working hard to improve the learning of students who are often distracted and who lack motivation with regard to their studies. We could only laugh in exasperation as we shared our favorite "sit-com" moments from the day about students who randomly pop out of their seats or chat with friends in the middle of what we consider to be interesting lessons. We all agreed that this reality and scenario is probably found in every school, in every school day, and in every kind of student. But as we got to thinking about it, we asked ourselves, "Who would want to sit all day long, between four walls, and not be encouraged or allowed to be active and move around?" It was at that moment another fitness-minded teacher and I realized rather than philosophizing about how a school day should be, we should effect 
the change we wanted to see. We decided to start an early morning fitness program called "Early Birds" that would be open to all students, free of charge, and operate three days a week. Our mission was to determine if purposeful, vigorous exercise before school might have an impact on the focus and achievement of our students during the school day.

On that first morning, we really had no idea what to expect. I had butterflies all night thinking about everything that could go wrong. What if someone gets hurt? Given that we were taking students on a 1.4-mile run through the streets of downtown New London, the possibilities of problems cropping up were numerous. Waiting for the first child to arrive, I worried that we had made a terrible mistake.

On that first morning, nine students participated. We hit the pavement with one teacher in front and one teacher in back. The students were safe but not entirely motivated. Some students were walking and taking breaks while others complained of how tired they were. We found the challenge of trying to balance the different levels of motivation and ability in students as we ran outside similar to dealing with this same problem in the classroom. We asked students to run in place until their classmates caught up, and completed the mile as a group. Beyond running the 1.4 miles we wanted students to increase their heart rates to above 140 beats per minute to make sure their workout was rigorous. To accomplish this we added in sprints, relay races, and calisthenics in intervals where we measured and recorded each child's heart rate. This allowed us to track the fitness level of every child and make sure each one was an active participant.

We had our doubts during this first day, but when I stood outside the changing rooms I knew that something positive was happening. The students were all laughing and teasing each other in an honest, accepting way, clearly enjoying the experience.

The program continued for 12 weeks until the end of the school year. The students showed considerable progress in their fitness levels. Our observations and other records indicated that these same students were also demonstrating improved motivation and focus in the classroom.

We believed that for the program to be successful it was critical that parents understood its purpose and supported it. We were pleased when a number of them began running with us in the first year to join in on the fun and to help with safety concerns. We attribute the success that time as much to the parent involvement as to the nine students who participated. 
During this first year, we noticed that many students were wearing the same clothes every run, and then proceeding to wear these same clothes again to school. The students wore basketball high-tops, football cleats with holes, or whatever they could find. As $72 \%$ of our students are on free and reduced lunch, we knew that, as a group, their financial resources were limited. Yet, lacking the latest in high-tech running gear did not keep these students from showing up every morning ready to go. Clearly, we were onto something.

As we entered the second year of the Early Bird program, we wanted to reward the dedication and desire the students were exhibiting. Their team spirit and pride in their hard work and accomplishments was palpable. Yet, they still did not quite look like the team they were clearly becoming. It was at this point that we decided to make T-shirts for Early Bird members. A parent who is a tattoo artist volunteered his artistic ability and designed a logo. The school paid for the T-shirts and in 3 weeks each child was given a new Early Bird jersey! We were humbled by the reaction of the students who wore them regularly. They seemed so proud to be a part of a team, and to have earned these shirts. What began as an effort to improve student focus and achievement through exercise clearly had become much more than that. Early Birds has inspired us as teachers by providing us with a much deeper understanding of our students and a stronger connection to the community around our school.

The program is now in its third year: 42 students, 2 parents, and 6 staff members are now involved. In reflecting on our original purpose, we are left with several key questions: How does exercise impact learning? Is it just the exercise that is impacting student learning or is it something deeper and more complex? Are the relationships students are building with adults outside of the classroom in the early morning hours impacting their motivation in the classroom? Is the self-esteem that results from the students' knowledge of the physical results of hard work having an impact on their perseverance in the classroom?

We believe our Early Birds program is having an impact on student achievement for two reasons: 1 . Research has shown that physical exercise and elevated heart rate do have a positive physiological impact on brain functioning and brain development (Hillman, Erickson, \& Kramer, 2008). 2. Relationships built between students and adults outside of the classroom can positively impact students' perceptions of school. Our conclusion is that schools in the 21 st century cannot continue to operate on the old paradigm of learning between the hours of 8 a.m. and 3 p.m. Schools today have to offer more to students including programming before and after school. By offering more meaningful activities like a fitness club before school and helping students to 
see the relationship between their physical fitness and their academic success, we are noticing a significant reduction in the achievement gap. Students who are members of the Early Bird Program are demonstrating fewer behavior referrals, higher attendance rates, and higher grades. We think Early Birds is about the value of educating the whole child: their physical fitness, their self-esteem, and their academic focus. Research on the effects of exercise on adolescent brain development suggests that we are onto something important (Ratey, 2008).

In their book, Spark: The Revolutionary New Science of Exercise and the Brain, Harvard psychiatrist Dr. John Ratey and Eric Hagerman (2008) document what many people have long felt, that exercise helps increase one's ability to think and perform. An increase in blood flow to the brain allows for more cellular growth of the brain cells, called neurogenesis. It is this phenomenon that is known to help the process of learning, decision-making, and other regulatory processes. The movement also helps release various chemical and hormones in the body that are linked to increased pathways in the brain (Casarez, 2010). Many people who run or exercise regularly have experienced this "feeling" of clarity and enhanced alertness. Ratey and Hagerman's book further suggests to us that the Early Bird program might provide more to our students than just enhanced focus-early bird exercise might also lead to brain cell growth.

As year three of Early Birds unfolds, we have designed the program to offer greater variety and levels of activities. In addition to distance running and calisthenics, we now also offer dance classes, floor hockey, and zumba as alternatives when some kids do not want to participate in the daily run. Offering more workout options has generated more interest in the program while allowing us to keep the group of students in each activity at a safe and manageable number. We have expanded to become year round and while our runs have grown colder, our numbers are holding steady. The students are now participating in record numbers, the smiles are always there, and recently members of the United States Coast Guard Academy have even began joining us on our morning runs! This program that started with a couple of fitness-minded teachers who wanted to see how exercise might help their overactive and antsy students has now blossomed into a school-community partnership. Students, staff, parents, and community partners are all getting into the Early Bird fitness kick. We are seeing significant results in the achievement of our Early Bird students. As previously mentioned, students who regularly attend Early Birds have stronger attendance, are earning higher grades, and have fewer behavior referrals. We are even starting to see improvement on school-wide benchmark tests and the state standardized tests for students who have participated in Early Birds for 2-3 years in a row. 
What is the relationship between student achievement and socio-economic background? Research has shown that dropout rates tend to be higher for children who live in poverty (Education Week, 2012). According to the U.S. Department of Education's 2011 Condition of Education report, about 68 percent of 12th-graders in high-poverty schools graduated with a diploma in 2008, compared with 91 percent of 12th-graders in low-poverty schools (NCES, 2011).

Given these facts, we believe we need to look more deeply at the research on exercise and its relationship to engagement and success for students who live in poverty. In the meantime, it is our hope that our school will adopt this now informal program as part of the required school day. We are determined to help lower the achievement gap at our school, provide better options for our students, and we strive to grow students' self-esteem and self-worth. A program such as Early Birds, where students begin the day with vigorous exercise, would be a key first step. More than just feeling good, it is about building on the science of how regular and rigorous exercise impacts body chemistry, brain development, and learning (Hillman et al., 2008). We believe exercise is as vital to learning as proper nutrition. Students must be given all the tools to be successful and our public schools can do more to invest in these tools. Extending the school day will allow for such programs to enhance the day and provide needed energy outlets for students.

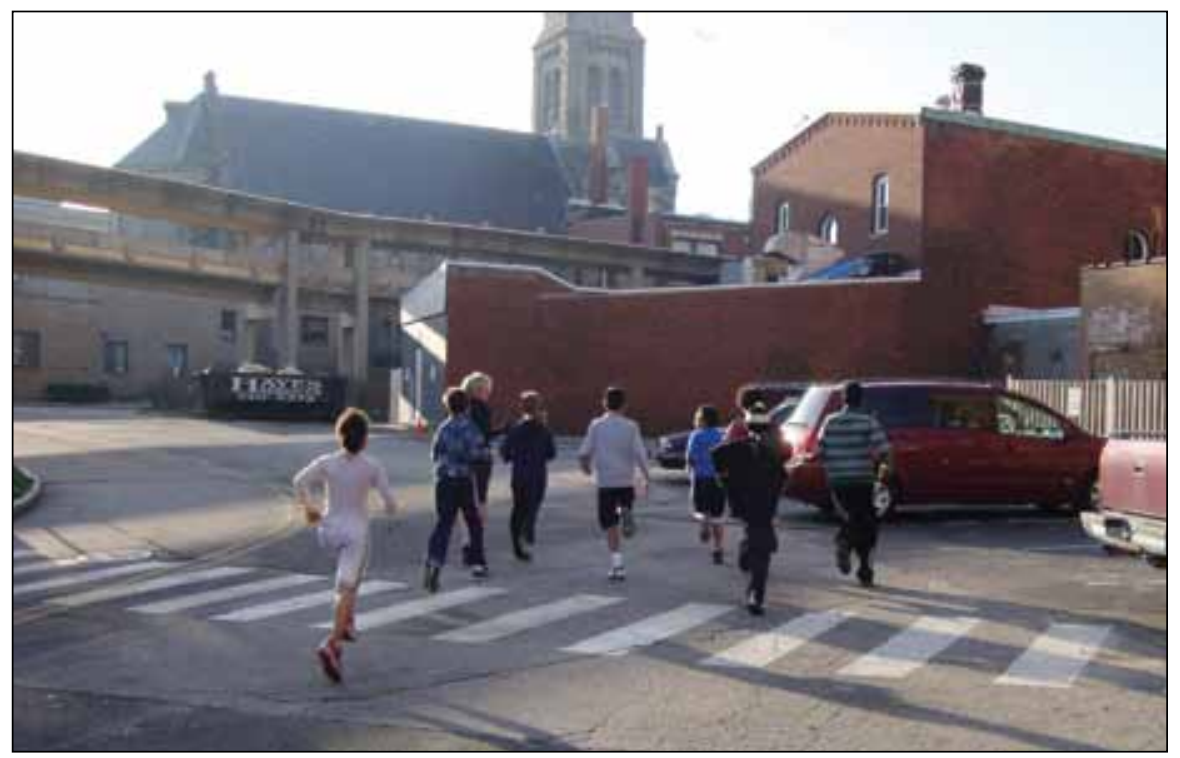

Fig. 1: Early bird members in full flight 
According to recent data, the diagnosis of students with ADHD has increased more than $2 \%$ in the past 10 years. In an article posted by msn.com, "Nearly 1 in 10 children in the United States is being diagnosed with attention deficit hyperactivity disorder, according to a new government study" (Carroll, 2011). In this same article, Dr. Bradley Peterson, an ADHD expert, explained,

We are increasingly more academically, cerebrally, and intellectually focused than we were two, three, five decades ago. And our requirements for kids to do well in school - having to sit still, stay focused, and attuned - have changed over time. I think the tolerance and threshold for saying a particular child is too fidgety, too distracted, has likely changed over time, too. (Carroll, 2011)

We need to reconsider how we educate and what our school day is providing for our children. We can significantly help our kids' health, self-esteem, and academic achievement by providing regular, rigorous exercise programs that are mandated as part of every school day. It is our hope that Early Birds will serve as a manageable model for schools to implement quickly, effectively, and continuously as part of the learning day. Our aim is to grow healthy and happy young adults who will have the tools necessary to be successful in an increasingly demanding, stressful, and fast-paced world.

\section{References}

Carroll, L. (2011, August 18). 1 in 10 US kids has ADHD, study finds. Retrieved January 13, 2012, from http://www.msnbc.msn. com/id/44190936/ns/health-childrens health/t/us-kids-has-adhd-study-finds/\#. TxGeEXO1no0

Casarez, R. (2010, September 2). Does exercise improve learning in children? Retrieved January 13, 2012, from http://www. livestrong.com/article/226065-doesexercise-improve-learning-in-children/

Hillman, C.H., Erickson, K.I., \& Kramer, A.F. (January 2008). Be smart, exercise your heart: exercise effects on brain and cognition. Nature Reviews. Neuroscience 9, 58-65.
Retrieved June 8, 2012, from http:// www.nature.com/nrn/journal/v9/n1/abs/ nrn2298.html

National Center for Education Statistics. (2011). "Condition of education 2011." Retrieved January 13, 2012 from http://nces.ed.gov/ programs/coe/analysis/2010-section3b. asp.

Ratey, J., \& Hagerman, E. (2008). Spark: The revolutionary new science of exercise and the brain. New York: Little, Brown and Company. 


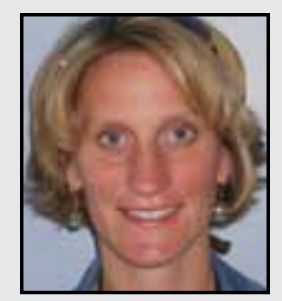

Heather DeLaurentis is a 6th grade science teacher at ISAAC, an urban charter school located in New London, Connecticut. Through project-based learning and movement, Heather strives to excite all students about learning and the importance of their education. Outside the classroom Heather organizes white water rafting trips, community garden programs, and several local community partnerships that bring mentors into the classroom. In her free time, Heather loves to water and snow ski with her two boys and husband.

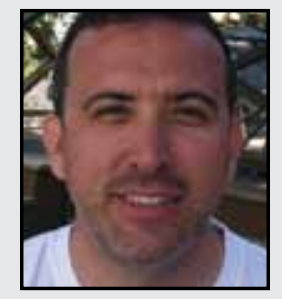

David Howes is a school designer with Expeditionary Learning (EL), a non-profit organization and a national network of schools. In his present role, David coaches teachers to create schools that challenge students to think critically and take active roles in their classrooms and communities. Prior to working with EL, David was a middle school social studies teacher and lacrosse coach for 13 years. In his free time, David loves to play with his two children and wife in their backyard and at the beach.

LINKTO:

http://www.elschools.org

http://www.isaacschool.org/hdelaurentis 